Mycoplasma pneumoniae の感染に 伴つた myelo-radiculo-neuritis の 1 症例

\author{
国立名古屋病院神経内科 \\ 臼井康臣 ${ }^{\diamond}$ 岡本進 \\ 国立名古屋病院内科 \\ 升田 隆雄恒川 洋 \\ 名古屋大学第一内科 \\ 向山昌邦
}

\title{
A CASE OF THE MYELO-RADICULO-NEURITIS ASSOCIATED WITH INFECTION OF MYCOPLASMA PNEUMONIAE.
}

\author{
Yasuomi Usui, M.D. and Susumu OKamoto, M.D. \\ Department of Neurology, Nagoya National Hospital. \\ Takao Masuda, M.D. and Hiroshi Tsunekawa, M.D. \\ Department of Internal Medicine, Nagoya National Hospital. \\ Masakuni Mukoyama, M.D. \\ The First Department of Internal Medicine, Nagoya University School of Medicine.
}

\begin{abstract}
概要 Mycoplasma pneumoniae (M. pn.)に伴万神経系の障害のうちpolyneuritis例については欧米で 若干例の報告があるのみで，本邦では未だ報告されていない，著者らは知覚障害優位のmyelo-radicu一 lo-neuritisの 1 症例に和いて，その病因としてM.pn. の感染が想定された希有なる症例をここに報告 した. 症例は23才の男性. 発熱，気道感染症状に続いて四肢の運動，知覚障害が出現. 入院時（第 9 病日）扁挑, 表在リンパ節の腫脹を認めた。神経系では, 意識清明, 項部強直なく, 脳神経系ではV VII脳神経障害, 四肢, 躯幹の異常覚, 腱反射の高度低下, 四肢末梢優位の軽〜中度の表在覚, 上肢に 高度，下肢に軽度の深部覚障害が認められ，また觔力も軽〜中度の低下を示した。臨床検查上，血沈 の促進, 寒冷凝集素価の上昇を認め, 血清M. pn. に対するC F 抗体価は初回64倍, 以後低下を示し た。一方fermentation inhibition抗体価は初回16倍，以後最高 128倍に達した。䯣液では，細胞数は 初回114/3 と增加を示したが以後は正常化し，細胞蛋白解離現象が認められた．腓腹神経生検像では 中〜高度の軸索, 髄鞀の変性, 脱落像が認められ，かつ太い線維により著明であつた. steroidの投与 により 4 カ月後に四肢の知覚障害を残して退院した。 M. pn. 感染に伴う polyneuritis の既報告例を検 討し，知覚障害優位を示した本拝例の特異性を指摘した。またM. pn.Kよる神経系障害の機序上し て，直接侵襲およびアレルギー性機序などについて考察を加えた。
\end{abstract}

はじめに

Mycoplasma pneumoniae(以下M.pn.と略す)に

〔昭和50年12月 4 日受稿〕
伴う神経系の障害にかんして，従来脳括よび䯣膜 炎については内外の文献に括いて比較的多くの報 告1) 7)がみらるが，急性または亜急性のpolyneuritis例については，欧米において若干の報告8)8) 
12)があるにすぎず，本邦では未だ報告されていな い.

ここに著者らは, 知覚優位, ことに深部覚障害 の著明なmyelo-radiculo-neuritisの一症例におい て, 寒冷凝集素価和よびM. pn. の抗体価が 上昇 を示し，その病因としてM. pn. が想定された症 例を経験したので報告し，併せて文献的考察を加 えたい.

\section{症例}

患者：23才, 男, 職業, 菓子卸店のトラック 運転手。

家族歴およひ既往歴： 特記すべきものなし. ツ反応は学童期に陽転.

主訴：四肢の運動, 知覚障害.

現病歴： 昭和 49 年11月23日夜, $39^{\circ} \mathrm{C}$ の 発熱 ( 3 日間持続), 次いで翌朝鼻汁, 少量の喀痰が出 現.この頃より左手指のびりびり覚に気づいた。 同日夕方には上肢全体に及び，つつぱり感をも伴 つた。11月26日には右上腕以下に，さらに両大腿 以下のびりびり覚および舌尖の焼ける様な異常覚 も加わつた．また歩行時, 特に階段を昇る際に下 肢がふらつくこと，握力低下等にも気づいた，経 過中, 頭痛, 呕気, 呕吐, 排尿执よび排便障害等 には気づいていない。

同年11月29日本院神経内科外来に初診. 四肢腱 反射の中ないし高度の低下, 四肢の異常知覚, 表 在, 深部覚の軽度低下, 筋力の軽度低下を指摘さ れた。12月 1 日より症状は悪化し, 翌12月 2 日入 院.

入院時現症（第 9 病日）：体格㧍よび栄養； 中等度, 体温 $36.2^{\circ} \mathrm{C}$, 血圧 $120 / 80 \mathrm{~mm} \mathrm{Hg}$, 皮膚 および粘膜に貧血，黄疸を認めない，扁桃は発赤 および中等度の腫脹を示した，表在リンパ節； 両側腋窩および鼡径部に各々 $2 \sim 3$ 個の $3 \sim 5 \mathrm{~mm}$ 大，軟かいリンパ節を触知した．胸部；心音は 純，呼吸音ではラ音を聴取しない，腹部で肝， 脾, 腎は触知しない。神経系; 意識清明, 精 神, 知能および言語機能は正常. 項部強直は認め られない。

脳神経系； 眼底所見で乳頭の境界は鮮明. 発

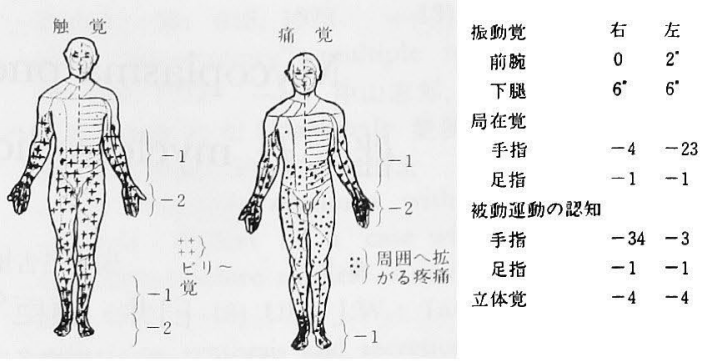

図 1。知覚（入院時，第 9 病日）

赤および裉色なし. 三叉神経は舌尖のびりびり覚 および砂の附着している様な異常覚あり，咬筋反 射および咬筋力は正常範囲内. 顔面神経では眼輪 および口輪筋にわずかな筋力低下が存在する. III，IV，VI，VIII～XII脳神経には異常は認められな かつた。

四肢, 躯幹 筋萎縮および異常運動なし，筇緊 張は正常. 腱反射; 上肢で, 上腕二頭筋および 上腕三頭筋反射消失, 尺骨および橈骨反射は中等 度低下，下肢；膝蓋およびアキレス腱反射消 失. 筋力：上肢近位部に軽度, 遠位部に中等, 下肢に軽度の低下を認める。

知覚 (図 1)：表在覚では，四肢に末梢優位 の軽度より中等度の知覚鈍麻が存在し, 上肢捛よ び第 9 胸髄節以下には触刺激によりびりびり覚， 針刺激により周囲に拡がる疼痛を伴つた異常覚が 存在していた。深部覚では, 振動覚, 局在覚, 被 動運動の認知など何れも上肢では高度, 下肢では 軽度の低下を示した。また手における立体覚障害 あ高度であつた。

歩行では足底が床に触れると不安感を訴え，べ ッドにつかまりながら, broad baseでゆつくり小 股で歩き，かつ失調性を示した。

\section{臨床検查所見}

一般検查：表 1 に示す様に血沈の促進，白血 球の減少傾向, 寒冷凝集素価は64倍と上昇, 血清 $\gamma \mathrm{M}$ globulinの増加を認めた以外には，ツ反応， 胸部 $\mathrm{X}$ 線写を含めて 異常所見は認められなかつ t.

ウイルス 学的検查： 血清，入院時（第 9 病 


\section{表 1.一般臨床㭘查所見（初診および入院時）}

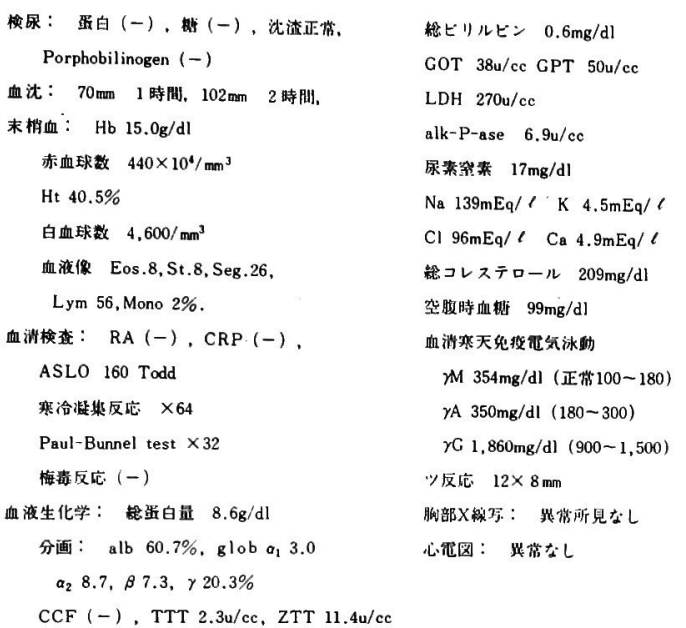

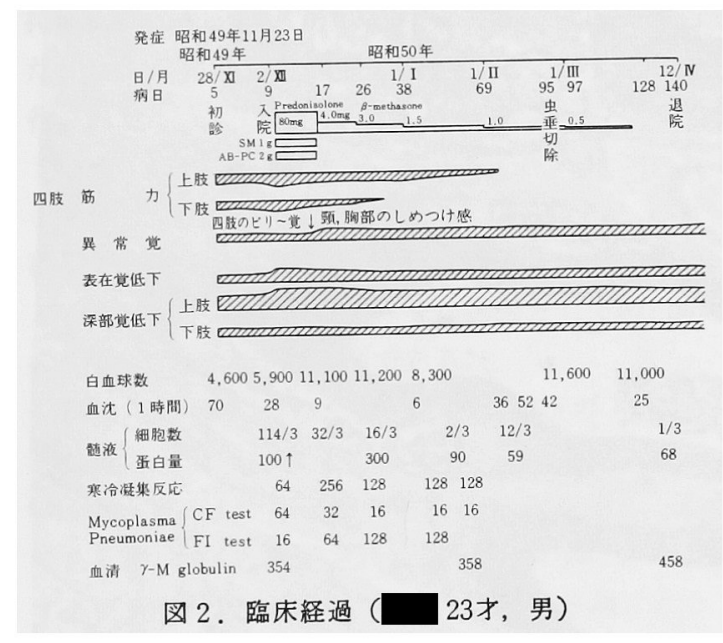

日).

補体結合反応 (CF test); M. pn. ×64. Influenza A, B, Adeno, Mumps, Psittacosis, Polio 1, 2, 3, Coxackie B1, B2, B3, B4, B5, B6, ECHO 4, $6,7,9$, 日本脳炎いずれも $\times 8$ 以下.

Fermentation Inhibition test (FI test); M. pn. $\times 16$ ，入院後(図 2 )。第 17 病日, 寒冷凝集素価 が256倍に上昇を示したため, 血清M. pn. の抗体 価をC F およびFI testにより経時的に測定した。 抗体価はCF testでは漸减を示したが，FI testで は第26病日には 128倍に上昇を示した事実によ
り，M. pn. による感染が考えられた.

髄液（第52病日）ではM. pn. の抗体価は× 1 以 下であり，M. pn. の分離 ( P P L O培地使用), virusの分離（HeLa，FL，Vero細胞）はいずれも 陰性であつた。

\section{酭液検查：}

初回（第 9 病日）。初圧 $140 \mathrm{mmH}_{2} \mathrm{O}, 7 \mathrm{cc}$ 採液 後 $90 \mathrm{mmH}_{2} \mathrm{O}$. 水様透明. 細胞数 $114 / 3$ (小単核 球 $90 \%$, 多核球 $10 \%$ ), 蛋白量 $100 \mathrm{mg} / \mathrm{dl}$ 以上, globulin反応 : Nonne-Apelt (+), Pandy (H). tryptophan反応 $(+)$, 糖 $90 \mathrm{mg} / \mathrm{dl}$. 一般細菌, 真菌拉 よび結核菌は塗抹，培養共にすべて陰性.

第17病日には細胞数は $32 / 3$ と減少し, 第 30 病日 以後は正常値を示した．蛋白量は第30病日におい ても 300mg/dlとな増加を示したが，第73病日に は60mg/dl以下に低下した，globulin反応は常に陽 性を呈した。

\section{笳電図検查 :}

初回 (第11病日). 安静時, 異常放電は認められ ない. 随意収縮時, 小指外転筋, 大腿直筋, 前怪 骨笳扣よび腓腹筋に軽度の放電頻度の減少が認め られた．MC Vは尺骨神経右 $58.7 \mathrm{~m} / \mathrm{sec}$., 左 52.7 $\mathrm{m} / \mathrm{sec}$, 腓骨神経 右 $46.7 \mathrm{~m} / \mathrm{sec}$., 左 $36.7 \mathrm{~m} / \mathrm{sec}$. で 低下は認められなかつた。

第 2 回（第51病日）.随意収縮時の放電頻度は正 常に復したが，右橈骨手根伸筋および小指外転筋 に $5 \sim 8 \mathrm{mV}$ の高振幅波が混在した。

腓腹神経生検所見（第24病日）

光顕像：髄䩗染色では(図 $3 \mathrm{a}$ ), 中等度の䯣 鞘の脱落, 崩壊像, Schwann細胞および神経内膜 の増生, 軸索染色においても(図 $3 \mathrm{~b}$ ), 中〜高度 の神経線稚の变性, 断裂, 脱落像が認められ, こ とに太い線維の脱落が著明であつた。

電顕像（図 4）：光顕像に対応して大型線維 が少ない.Schwann細胞々体内には多数の大小の 空胞および髄䩗の崩壊産物と考えられる物体が含 まれており，またほら゙正常構造を有すると考えら れる有髄線維の中にも, axon内户Schwann細胞内 にmyelin様構造物を含む部分が認められた。 


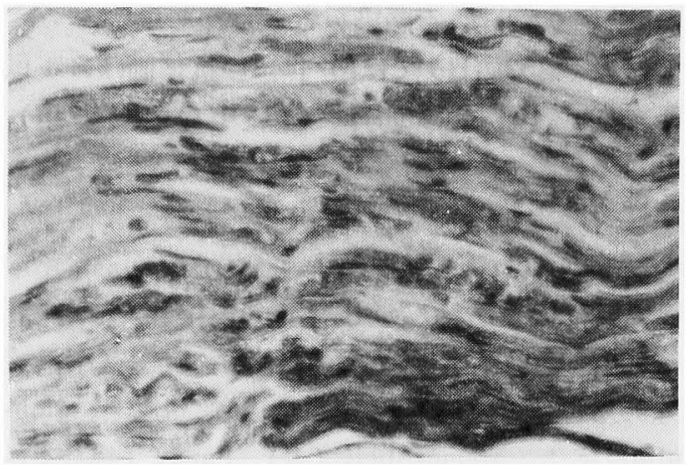

因 3 a. 噵輎 中等度の変性, 脱落を示し, Schwann細 胞の增生がみられる. Masson Trichrome染色 $\times 200$

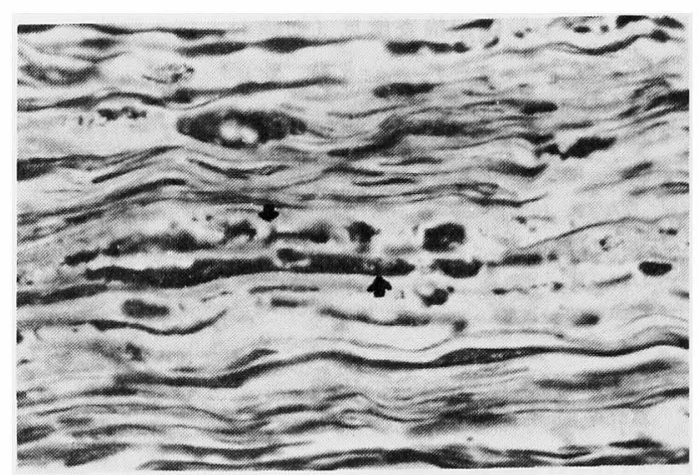

図 3 b. 軸索 中等度の变性, 断裂, 脱落を示し, とく に太い線維に著明である（ $\downarrow$ 印）. Bodian染色 $\times 400$

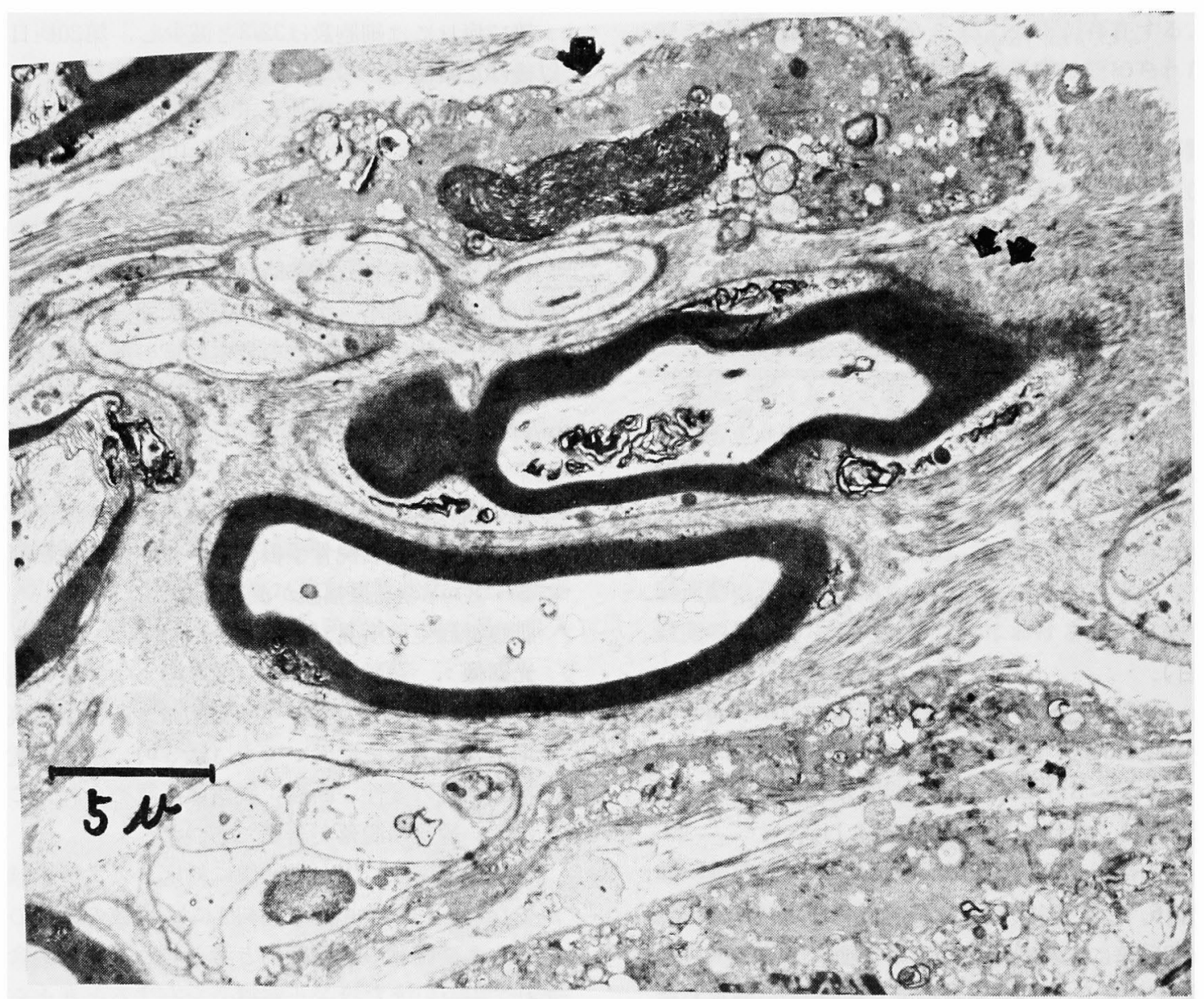

図 4. 電顕像. Schwann細胞胞体内に大小の空胞および䯣鞘の崩壊産物と考えられる物体を含む( ほほ正常構造を有すると見られる有葡線稚でも，Schwann細胞胞体内やaxon内にmyelin様構造物が含まれ ている( $\downarrow$ 印). $\times 5,700$ 


\section{経過（図 2)}

当初はstreptomycin, aminobenzil-penicillin prednisolone80ng (1 日量) の非経口的投与を 1 週間行なつたところ, 前述の様に髄液細胞数は 32/3と減少を示した。次にbeta-methasone $4 \mathrm{mg}$

（1日量）の経口投与に切りかえて，以後漸減し た.この頃ょり四肢の筋力低下おょび知覚鈍麻は 改善の㑯向を示したが, 四肢, 躯幹の異常覚は存 続した。一方, 㳭部覚障害は上肢でやや軽隇を示 したが依然高度を呈し，下肢でも軽度の障害が持 続し，かつ頝部および胸部のしめつけ感を訴えて いた．筇力は顔面，下肢では第30病日頃，上肢で は第70病日頃には正常に復し, 四肢腱反射む徐々 に回復の傾向を呈した．しかし知覚障害は同様に 持続し，昭和50年 4 月12日（第 140病日）退院し た。なお 2 月26日急性虫垂炎を併発し，手術が施 行された。

\section{考 案}

本例は急性気道感染症に続いて，知覚，こと に深部覚障害優位のmyelo-radiculo-neuritis像を呈 し，血清学的検索に基づいて，病因としてM. pn. の感染が想定された症例である。

1944年Eatonkよつて原発性異型肺炎の患者か ら分離されたいわゆる“Eaton agent”が，1962年 Chanock等により原発性異型肺炎の起炎菌の一つ であるM.pn. と同定されて以来，M.pn.にかん する研究が一段と進歩した．人体から分離される Mycoplasma 8 種類のうち, 人体に病原性を有す るものとしてM. pn. が知られており，M. pn. は 健康者に常在することは少なく，潜伏期間は 2 一 3 週間, 疾患として上気道炎, 気管支炎, 肺炎な ぞの急性気道感染症, 中耳炎, 多発性関節炎, febrile mucocutaneous syndrome等を括こし，い ずれも予後が良好であることが知られている9 15)17)

M. pn. の診断には，M.pn. の分離または抗体 価の測定が用いられる。一般に検体からM. pn.の 培盖, 分離, 同定の成功率は低いために, 血清学 的診断法が使用されている.すなわちM. pn. 感染
例では寒冷凝集素価の高値を示す例が多いこと， および寒冷凝集反応陽珄例の72〜92\%は血清M. pn. 抗体価むまた上昇を示すといわれて1417，従来 から多くの例に拈ける本症診断は，寒冷凝集素価

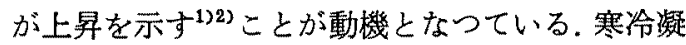
集素価，M. pn. に対する血清 C F 抗体価，抗よび 増殖抑制試験としてM. pn. に特異的であるとい われる血清fermentation inhibition抗体価の 3 者 の推移では，寒冷凝集素価と C F 抗体価は共に発 症後 2 週間頃より上昇し，第 4 週に最高值に達す るのに対し，FI抗体価はこれら 2 者よりやや遅 れて，発症第 3 週頃上り上昇し，第 7 週に最高值 に達するといわれている14).

M. pn. 感染症における神経系障害をみると, 畄 および髄膜炎については本邦に执いても数例の報

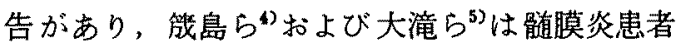
の䯣液よりM. pn. の分離に成功したことを述べ ている. 脳, 髄膜炎の頻度にかんして, 升田は14)

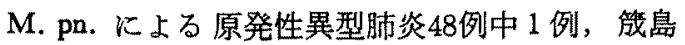
ら”はM. pn. に上る呼吸器感染46例中 2 例におの おの䯑膜炎を併存したと述べている。

一方polyneuritisを示した症例は文献上 9 例が報 告されている。これら9例の臨床経過の概要は表 2 に示した通りである，大部分は若年例で，発 熱, 呼吸器感染症状を初発症状とし, 次に 2 週間 以内に神経症状が出現している.神释症状では， 脳神経系ではV, VI, VII, X脳神経障害が指摘さ れ，四肢では運動障害優位である，䯣液では細胞， 蛋白解離が認められ，予後は良好で大部分の症例 は 5 力月以内に軽快し、いわゆるGuillain-Barré typeである。自験例に打いて病変の主要な存在部 位は四肢の末梢神絟と考学られるが，知覚障害は 運動障害に比べてより顕著であり，知覚障害で は，表在覚と比べて深部覚障害がより高度で，か つ下肢と比べて上肢により著明であつたことは既 報告と比べて特異的であると考えられる．次に本 例では，第 9 胸䯣節にみられた横断性知覚障害の 存在, 佮液中の一過性細胞增多, 尺骨神経, 腓骨 神経の運動神経伝導速度が正常であること，なら 
表 2. Mycoplasma pneumoniaeによる急性多発性神経根炎の既報告例

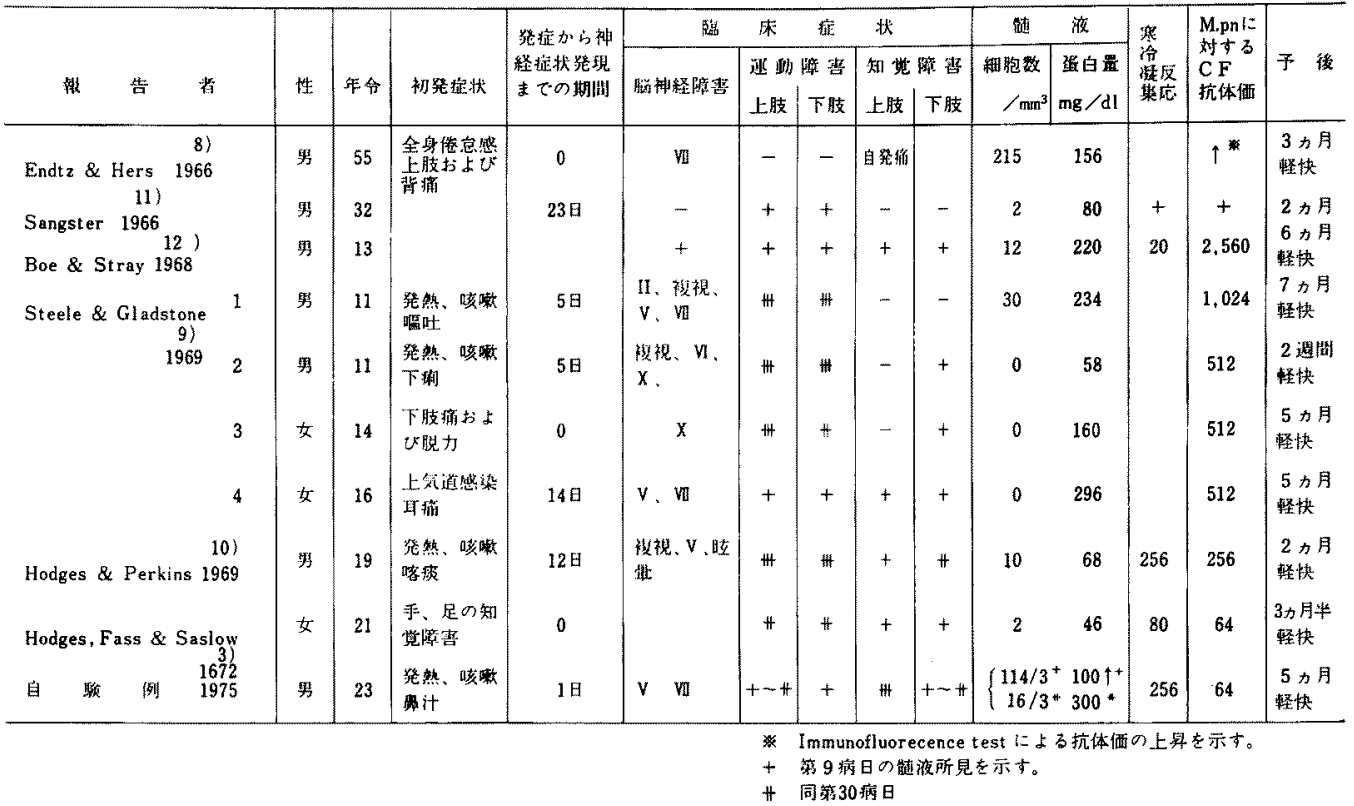

びに上述した㳭部覚優位の病像が脊䯣後索の病変 の可能性をも推定させる事実などは，polyneuritis に加充てmyelitisの併存をも考虑させる病像と思 われる。

M. pn.による神経系障害の作用機序として，1） 神経系への直接の侵襲または毒性作用 $\left.{ }^{288}, 2\right)$ 自 己免疫またはallergy性機序が考方多39)18) られてい る。

第1の可能性については，Thomasらは七面鳥 にMycoplasma gallisepticumを，またmouse $に \mathrm{My}$ coplasma neurolyticumのexotoxinを静脈内に注入 することにより，おのおの脳血管の血管炎 ${ }^{18}{ }^{18}$ お び脳の皮質，白質に海面状の限局性病巣をつく $\eta^{19)}$ ，これらの病因としてMycoplasmaの直接的 な，toxic actionが考えられると述べていること， M. pn. に上る䯣膜炎患者の䯣液よりM. pn. の培 養に成功した報告（既述）から，M，pn. 6人間 について家音と同様に直接侵襲を来たすことが想 定される233。

第 2 の可能性については, M. pn. の患者では寒 冷凝集反応, Coombs testが陽性を示すこと 経症状の有無に拘らずM. pn. に羅患した患者の
血清は，M.pn. 非䍜患者の脳, 肺, 肝扰よび cardiolipinと反応する抗体を有すること（Biberfeld $)^{16)}$ 等の事実は, M. pn. の感染過程中に人体に 対する異質の抗体が産生され，この抗体が自己の 神経組織化作用する自己免疫性，あるいはallergy 性の機序が考えられる. Biberfeld ${ }^{16)}$ 女文献を検討 ᄂ, M. pn. はglyco \& phospholipid等のlipidに富 んでおり，M. pn. に羅患した患者では血清中にこ れらのlipidと反応する抗体が産生されるために， この抗体がM. pn. 非䍜患者の脳等の組織lipidと 反応する可能性について述べている，自験例に 扣いては，呼吸器症状発現後翌日に，既に神経症 状が出現したこと，初期に䯣液の細胞数が増加を 示したことなどは，M.pn. による直接侵襲また

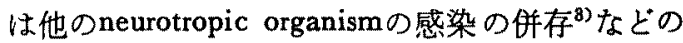
可能性を示唆するが，第52病日に施行された葡液 のM. pn. のC F 抗体価は× 1 以下であり，M. pn. および他のvirusの分離は陰性であつた。るとより この結果については，検查時期について問題があ るが，一方既報告例に括ける，M. pn.による多発 性神経根炎に打いて，急性期かつ髄液のM. pn.の 
C F 抗体価が上昇を示している症例においてる， M. pn. 分離に成功していないこと (Steele)" を゙ 考えると，神䅅系障害の発生機序としてallergy性 機序も想定されるが，現段階ではいずれとも確定 することは困難であろう．

\section{秸 語}

Mycoplasma pneumoniaeの感染に起因すると 考えられる知覚障害優位の希有なmyelo-radiculoneuritis例を報告した．

終りに臨み、ご校閲とご指導をいただいた国立名古屋 病院長，名古屋大学名誉教授日比野進博士に深懒する。

電影磦本の作製に際しご援助いただいた本院研究検查 科勝見清技官に対して厚くお礼申上げる。

\section{文嗝}

1) Sköldenberg, B.: Aseptic meningitis and meningoencephalitis in cold-agglutinin positive infection. Brit. Med. J. 1: 100 102, 1965. - 2) Taylor, M.J., Burrow, G.N., Strauch, B. and Horstmann, D.M.: Meningoencephalitis associated with pneumonitis due to mycoplasma pneurnoniae. J.A.M. A. 199: 813 816, 1967. -3) Hodges, G.R., Fass, R.J. and Saslaw, S.: Central nervous system disease associated with mycoplasma pneumoniae infection. Arch. Int. Med. 130: 277 282,1972. 4) 筬島四郎，他：Mycoplasm肺炎にっいて。耺会 誌, $41: 312$, 昭42. 一5) 大滰千佐子, 他: 渗出性肋 暯炎を伴える，マイコブラズマ肺炎の 3 症例找上 び, マイコブラズマによる槳液性随膜炎の1例. 感 染症学雑誌, $44: 35$, 昭 45. 一 一) 葛巻這, 梅津征 夫：Mycoplasma pneumoniae CF抗体価か高值を示

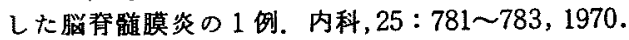
-7) 牧野定夫, 石井豊信, 栃木亮太郎, 鳥羽用, 数
馬欣一, 久保政次：Mycoplasma pneumoniae meningitisと思われる 1 例。小児科診㙩，36：1110 11 14, 炤48. -8) Endtz, L.J. and Hers, J.F.P.: Radiculonévrite causee par Mycoplasma pneumoniae avec présentation d'un cas. Rev. neurol. 114: 141 146,1966. - 9) Steele, J.C., et al.: Mycoplasma pneumoniae as a determinant of the GuillainBarré syndrome. Lancet 2: $710 \sim 713,1969,-10$ ) Hodges, G.R. and Perkins, R.L.: Landry Guillain-Barré syndrome associated with mycoplasma pneumoniae infecticn. J.A.M.A. 210: 2088 2090, 1969. - 11) Sangster, G.: Neurological complications of primary atypical pneumonia. Brit. J. Clin. Pract. 20: 89〜92, 1966. 文献3）より引用. 一12) Boe, J. and Stray, T.K.: Mycoplasma-pneumoni med svaer affetsjon av sentralnervesystemet. J. Norsk. Laegeforen 88: 2023 2026，1968. 文献3) 上り引用. -13) Steele, J.C., et al.: Acute cerebellar ataxia and concomitant infection with $\mathrm{my}$ coplasma pneumoniae. J. Pediat. 80: 467 469, 1972. - 14) 升田隆雄：Mycoplasma pneumoniae肺 炎に関する研究. 日胸会誌, $7: 234 \sim 245$, 昭 44 , -15) 中村昭司：マイコブラズマ感染症. 新内科学 大系. 感染症 III, 中山書店, 東京, 昭50, 385 3 97頁. - 16) Biberfeld, G.: Antibodies to brain and other tissues in cases of mycoplasma pneumoniae infection. Clin. exp. Immunol. 8: 319 333, 1971. -17) Chanock, R.M.: Mycoplasma infections of man. New Eng. J. Med. 273: 1257 1264, 1965. -18) Thomas, L., et al.: Studies of PPLO infection. I. The production of cerebral polyarteritis by Mycoplasma gallisepticum in turkey. The neurotoxic property of the mycoplasma. J. exp. Med. 123: 897 913, $1966 . \quad$-19) Thomas, L., et al.: Studies of PPLO infection. II. The neurotoxin of Mycoplasma neurolyticum. Ibid. 124: $1067 \sim 1083,1966$. 